M. M. Talerko', T. D. Lev' ${ }^{1}$, S. I. Kireev², V. O. Kashpur ${ }^{1}$, G. G. Kuzmenko ${ }^{1}$

${ }^{1}$ Institute for Safety Problems of Nuclear Power Plants, NAS of Ukraine, 12, Lysogirska st., Kyiv, 03028, Ukraine

${ }^{2}$ State Specialized Enterprise "Ecocenter", 6, Shkilna st., Chornobyl, 07270, Ukraine

\title{
Evaluation of Radioactive Air Contamination due to a Forest Fire within the Exclusion Zone on June 5-8, 2018
}

Keywords:

wildland fires, resuspension, radionuclide, atmospheric transport, modeling,

Exclusion zone.
The results of simulation of the radioactive aerosol atmospheric transport due to a fire in forest areas in the Chornobyl Exclusion Zone (near the ISF-2) during June 5-8, 2018 are presented. To assess its consequences, a modeling complex of the Institute for Safety Problems of Nuclear Power Plants was used, which includes a mesoscale weather forecast model WRF, model of convective plume formation over the fire area, and the Lagrangian-Eulerian diffusion radionuclide atmospheric transport model LEDI. Model calculations for the radioactive combustion products transport are carried out at a distance of up to $100 \mathrm{~km}$ from the fire area. The results of sampling of burned forest litter and upper layer of soil, made for estimation of total activity stock at the 2 fire sites, are presented. The average ${ }^{137} \mathrm{Cs}$ surface contamination density was obtained to be about $2.85 \mathrm{MBq} / \mathrm{m}^{2}$ (with a variability of this value from 1.02 to $5.40 \mathrm{MBq} / \mathrm{m}^{2}$ ). According to calculations, the maximum value of the ${ }^{137} \mathrm{Cs}$ activity in the surface air in Kyiv in some periods of the fire could reach values of about $1 \mathrm{mBq} / \mathrm{m}^{3}$, in Chornobyl - about $10 \mathrm{mBq} / \mathrm{m}^{3}$. The overall results are in agreement with the measurements of the ${ }^{137} \mathrm{Cs}$ activity in the air carried out by the network of Automated Radiation Monitoring System ASKRO posts of the SSE "Ecocenter", as well as air sampling data in Mila village of the Kyiv region (results of the State Scientific Technical Centre on Nuclear and Radiation Safety).

\section{Introduction}

The highly contaminated territories of Ukraine and Belarus after the Chornobyl accident still remain potential sources of radioactive contamination due to forest fires there, first of all within the Ukrainian Chornobyl Exclusion zone and the Belarus Polesie Reserve. The radionuclides in the vegetation and soil would be emitted to the atmosphere during vegetation fires, which could represent a risk for firefighters and other personnel of these zones. In addition, a population could be affected by radioactive smoke particles transported over long distances. So, an assessment of the possible influence of forest fires in radioactively contaminated territories on the radioecological situation in the Exclusion zone and beyond is of particular interest. Unfortunately, data of direct measurements of additional air contamination and fallout on the underlying surface during fires are usually quite scarce (both in spatial and in temporal resolution). Therefore, methods of mathematical modeling of the atmospheric transport of radioactive aerosols - products of vegetation burning - are an important tool for a comprehensive assessment of the effects of forest fires. 
The article presents a comparison of the results of calculations performed using the model complex developed in the Institute for Safety Problems of Nuclear Power Plants (ISP NPP) with direct measurements of the effects of the wildland fires in the Exclusion zone during June 5-7, 2018.

\section{Radionuclide emission due to wildland fires at radioactively contaminated territory (observation and modeling)}

The main source of radionuclide emission after wildland fires in the contaminated territories is the Chornobyl exclusion zone (ChEZ) with an area of $2,600 \mathrm{~km}^{2}$. The forests covered $53 \%$ of the area before the disaster. After 1986, economic activity stopped and the forest area extended. Now about $38 \%$ of the territory is Scots pine forests, $30 \%$ is broadleaf forests, and the other $32 \%$ is deforested and former agriculture areas [1]. The lack of fire management allowed the vegetation to overgrow, creating conditions favorable for fires to ignite and spread. The radionuclides ${ }^{137} \mathrm{Cs},{ }^{90} \mathrm{Sr},{ }^{238} \mathrm{Pu}$, and ${ }^{239+240} \mathrm{Pu}$ are concentrated mostly in litter and the top layer of soil in the forests and grasslands in ChEZ [2].
According to [3], from 1993 to 2013 more than 1,250 wildland fires of different types ancurred in the ChEZ. Approximately $55 \%$ of the fires occurred in former agricultural lands and about $33 \%$ occurred in forested land. Although these fires consumed only 3,300 ha of vegetation, larger fires have occurred in the region. The largest fires were observed in July-August, 1992 (a total area of 17,000 ha of agricultural and forest land including crown fire over an area of 5,000 ha during a two week period) and in April 2015 (6,250 ha of grass fires at meadows, 2,737 ha of forest ground fires and 1,140 ha of forest crown fires). According to the measurement data within the ChEZ, the activity concentration in the surface air increased up to $7.6 \mathrm{mBq} \mathrm{m}^{-3}$ of ${ }^{137} \mathrm{Cs}$ and $10 \mathrm{mBq} \mathrm{m}^{-3}$ of ${ }^{90} \mathrm{Sr}$ [4].

Besides the ChEZ itself, the wildland fires could impact the radioliogical situation outside it. The long-range transport of smoke plumes after the forest fires in the ChEZ and near it was observed by the satellites [5]. Increasing the ${ }^{137} \mathrm{Cs}$ activity concentration in the air was reported in Sweden [6] and Lithuania [7] during extensive forest fires in the radioactive contaminated territory of Ukraine and Belarus in 1987-2003. According to [8], several fires

Table 1. Radionuclide emission fraction during wildland fires

\begin{tabular}{|c|c|c|c|}
\hline Nuclide & Emission fraction & Source & Comments \\
\hline $\mathrm{I}, \mathrm{Cl}$ & $80-90 \%$ & \multirow{2}{*}{ [18] } & \multirow{2}{*}{$\begin{array}{l}\text { Straw and wood burning experiments in field and labora- } \\
\text { tory conditions. Biomass were combusted with tempera- } \\
\text { tures varying from } 160 \text { to } 1,000{ }^{\circ} \mathrm{C}\end{array}$} \\
\hline Cs & $40-70 \%$ & & \\
\hline${ }^{137} \mathrm{Cs}$ & $\begin{array}{l}10-40 \% \text { depending on the tempera- } \\
\text { ture (12\% after a cool burning and } \\
39 \% \text { after a hot burning) }\end{array}$ & {$[19]$} & $\begin{array}{l}\text { Laboratory experiments for heather burning } \\
\qquad \text { (50 kg of dried material) }\end{array}$ \\
\hline${ }^{137} \mathrm{Cs}$ & $\begin{array}{l}1 \% \text { of totally available within } \\
\text { the burnt area, or } \sim 10 \% \text { of available } \\
\text { in the biomass }\end{array}$ & {$[20]$} & $\begin{array}{l}\text { Estimation for modeling of inter- and intra-continental } \\
\text { transport of cesium released by boreal forest fires }\end{array}$ \\
\hline${ }^{137} \mathrm{Cs}$ & $40 \%$ of deposited & {$[13]$} & $\begin{array}{l}\text { Conservative estimation for modeling of redistribution } \\
\text { over Europe }\end{array}$ \\
\hline${ }^{137} \mathrm{Cs},{ }^{90} \mathrm{Sr}$ & $20 \%$ & \multirow[b]{2}{*}[11]{} & \multirow[b]{2}{*}{ Conservative estimation for modeling } \\
\hline $\begin{array}{l}{ }^{238} \mathrm{Pu},{ }^{239} \mathrm{Pu} \\
{ }^{240} \mathrm{Pu},{ }^{241} \mathrm{Am}\end{array}$ & $10 \%$ & & \\
\hline${ }^{137} \mathrm{Cs}$ & $\sim 3-5 \%$ of deposited & [21] & $\begin{array}{l}\text { Estimation value has been obtained after the natural } \\
\text { forest fire in the ChEZ in July, } 1992\end{array}$ \\
\hline${ }^{137} \mathrm{Cs}$ & $4 \%$ of deposited & {$[2]$} & Fire experiments in the ChEZ \\
\hline${ }^{137} \mathrm{Cs}$ and ${ }^{90} \mathrm{Sr}$ & up to some $\%$ o & \multirow{4}{*}[10]{} & \multirow{2}{*}{$\begin{array}{l}\text { Grassland fires (comparison of modeling and experimen- } \\
\text { tal data) }\end{array}$} \\
\hline $\mathrm{Pu}$ & up to $1 \%$ o & & \\
\hline${ }^{137} \mathrm{Cs}$ and ${ }^{90} \mathrm{Sr}$ & up to $3-4 \%$ & & \multirow{2}{*}{$\begin{array}{l}\text { Forest fire (comparison of modeling } \\
\text { and experimental data) }\end{array}$} \\
\hline $\mathrm{Pu}$ & up to $1 \%$ & & \\
\hline
\end{tabular}


in 2002 resulted in ${ }^{137} \mathrm{Cs}$ transport over Europe. The highest release occurred at the end of July, with ${ }^{137} \mathrm{Cs}$ fallout reaching Sweden, Finland, and Central Europe.

Wildland fires may result in additional contamination of the air both in the immediate vicinity of the fire territory and over long distances, including long-range atmospheric transport of fine aerosol. Therefore, different types of models of emission, following atmospheric transport and deposition of fire products are developed for the local area around the fire (up to $10 \mathrm{~km}$ ) $[9,10]$ and mesoscale and long-range atmospheric transport $[8$, 11-15]. The main features of the radionuclide atmospheric transport models for different spatial and temporal scales are determined primarily by the nature of the diffusion processes of pollutants in the atmosphere, and they are similar for both models of emissions from point sources - e.g., from a nuclear power plant (NPP) stack - and for the re-suspension models during forest fires. The main problem for models of forest fires is the correct description of the radioactive aerosol source parameters (duration and area of the fire, emission intensity for the different phases of the fire, the initial raising height of smoke plume, activity size distribution of radioactive particles). In general, a model of atmospheric transport of smoke particles must be a part of a more general model of wildland fire evolution $[16,17]$. Using a number of simplifying assumptions a subtask of assessment of radioactive contamination of the atmosphere by combustion products can be singled out of the general picture describing the development of the fire and its consequences. Then this problem can be solved by relatively simple methods. The price of such simplification is the introduction into used models a number of constants whose values have to be determined empirically.

One of the main problems of radionuclide atmospheric transport models due to forest fires is the parameterization of the emission fraction of radionuclide after a fire event, namely the fraction that will be emitted compared to what is present on the ground or in the biomass. Evidence from laboratory experiments and field studies are quite contradictory (Tab. 1).

Therefore, any available information about the consequences of past fires is an important material for the validation of models of atmospheric transport of forest fire products, as well as for their further improvement.

\section{General description of the forest fire on June $5-7,2018$}

During the period from June 5 to June 8, 2018, several areas of grass and forest were burned on the terri- tory of the 10-kilometer zone of the Chornobyl NPP. The most intense fires took place in two forest areas located near the Interim Spent Nuclear Fuel Dry Storage Facility (ISF-2) (Figs. 1, 2), where the seats of fire were detected about 11:00 on June 5, 2018 [22]. In total, according to the State Emergency Service of Ukraine, a fire covered about 15 hectares. At 17:50 on June 7 a fire in the forest area in the Exclusion zone was liquidated. During the fire, the personnel of the State Specialized Enterprise (SSE)"Ecocenter" made an air sampling at the fire line using the mobile aspiration facility, in particular, in the 16 th quarter of the Korohod forestry. The ${ }^{137} \mathrm{Cs}$ activity concentration in this sample was about $9.8 \cdot 10^{-2} \mathrm{~Bq} / \mathrm{m}^{3}$ that exceeds the reference level by 9.8 times, and the ${ }^{90} \mathrm{Sr}$ activity concentration was obtained to be $1.610^{-1} \mathrm{~Bq} / \mathrm{m}^{3}$ that by 53 times exceeds the reference level $\left(3 \cdot 10^{-3} \mathrm{~Bq} / \mathrm{m}^{3}\right)$ established by health and safety standards.

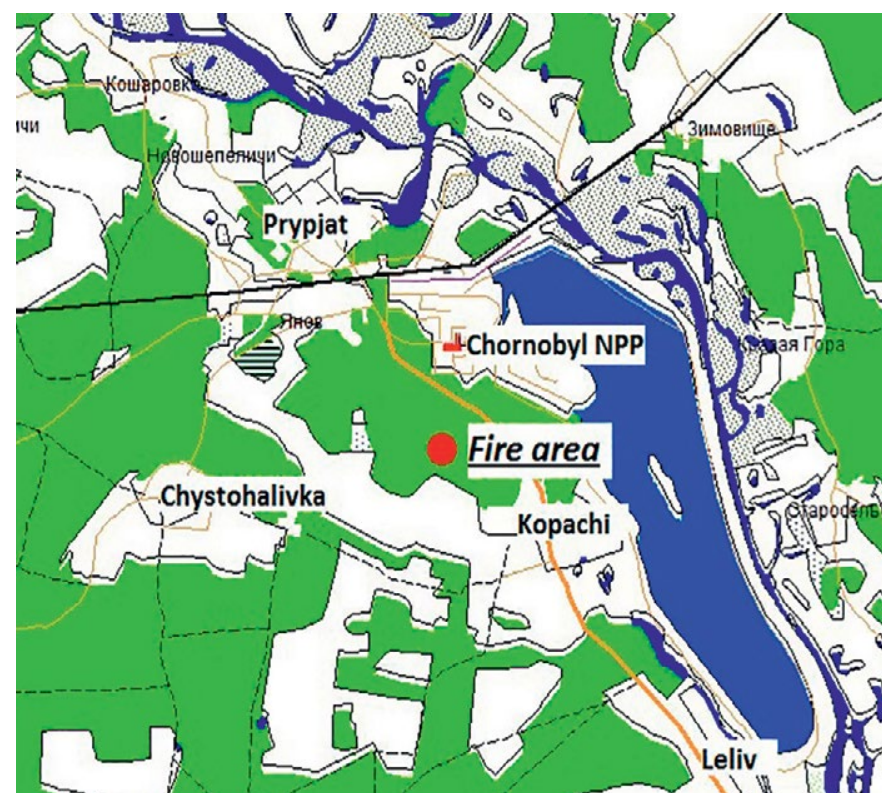

Fig. 1. Map of the location of the main areas of the fire

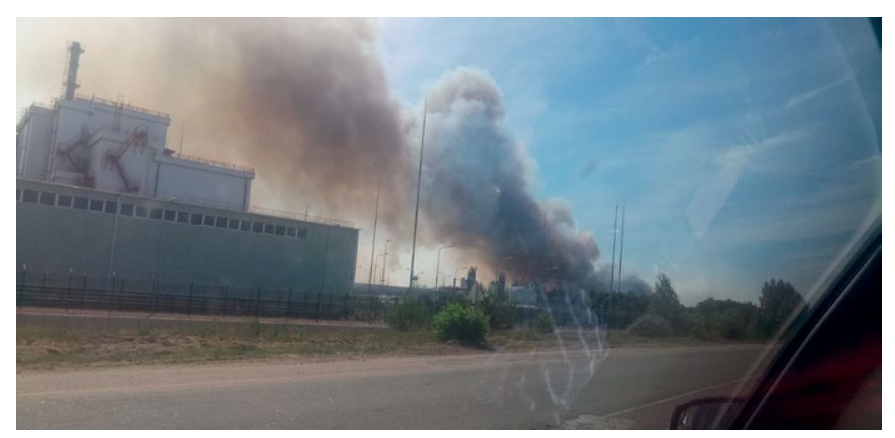

Fig. 2. Smoke plume from the fire at 15:00 on June 5, 2018. The ISF-2 building is in the foreground 
According to the measurements of the atmospheric surface layer contamination by radioactive aerosols conducted at stationary sites of the SSE "Ecocenter" automatic radiation monitoring system (ASKRO), the ${ }^{137} \mathrm{Cs}$ and ${ }^{90} \mathrm{Sr}$ volumetric activity concentration at the Chornobyl site exceeded the established control levels $\left(8.0 \cdot 10^{-5} \mathrm{~Bq} /\right.$ $\mathrm{m}^{3}$ and $4.0 \cdot 10^{-5} \mathrm{~Bq} / \mathrm{m}^{3}$, respectively). The ${ }^{137} \mathrm{Cs}$ volumetric activity concentration was obtained to be $2.2 \cdot 10^{-4} \mathrm{~Bq} / \mathrm{m}^{3}$ (at $1: 4006.06 .18$ ), $3.8 \cdot 10^{-4} \mathrm{~Bq} / \mathrm{m}^{3}$ (at $15: 0006.06 .18$ ) and $4.710^{-3} \mathrm{~Bq} / \mathrm{m}^{3}$ (sampling was made using a mobile aspiration facility from $15: 00$ to $18: 0006.06 .18$ ). The corresponding values for the ${ }^{90} \mathrm{Sr}$ volumetric activity concentration were $2.4 \cdot 10^{-4} ; 2.5 \cdot 10^{-4}$ and $2.3 \cdot 10^{-3} \mathrm{~Bq} / \mathrm{m}^{3}$.

At the exclusion zone border (Dytyatky site), the ${ }^{137} \mathrm{Cs}$ volumetric activity concentration on June 6 was $2.7 \cdot 10^{-5} \mathrm{~Bq} /$ $\mathrm{m}^{3}$ which didn't exceed the reference level $\left(2 \cdot 1 \cdot 10^{-4} \mathrm{~Bq} / \mathrm{m}^{3}\right)$.

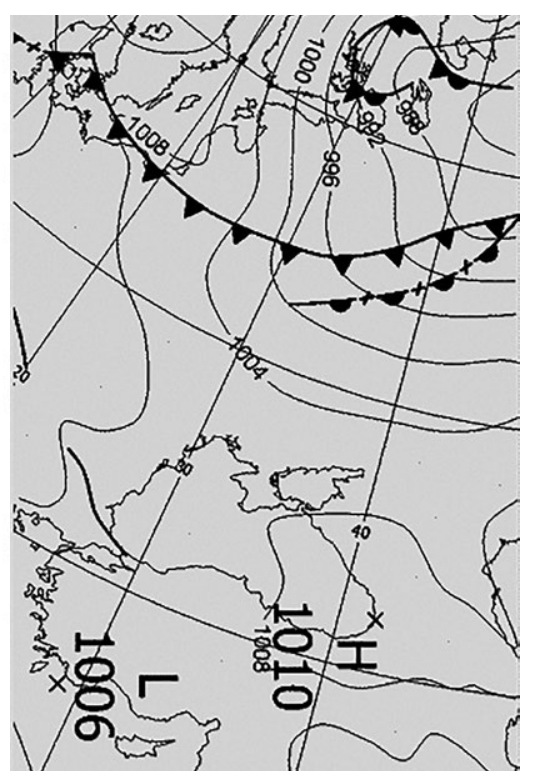

05.06.2018 00h

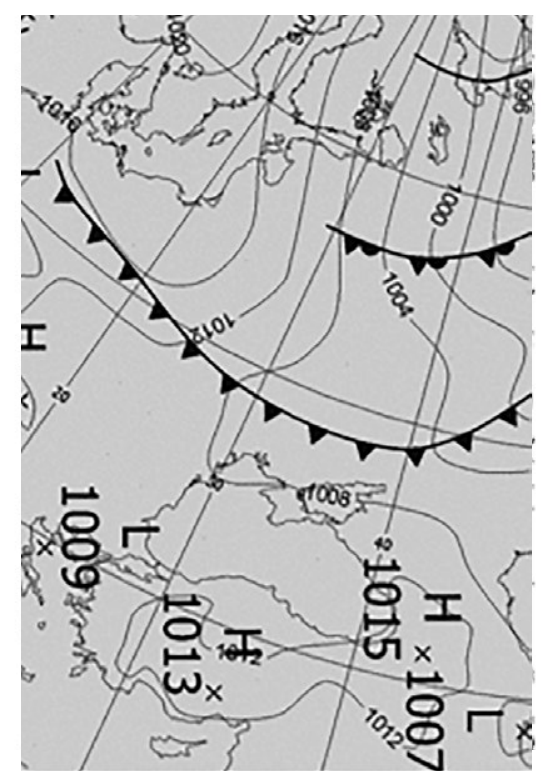

06.06.2018 00h

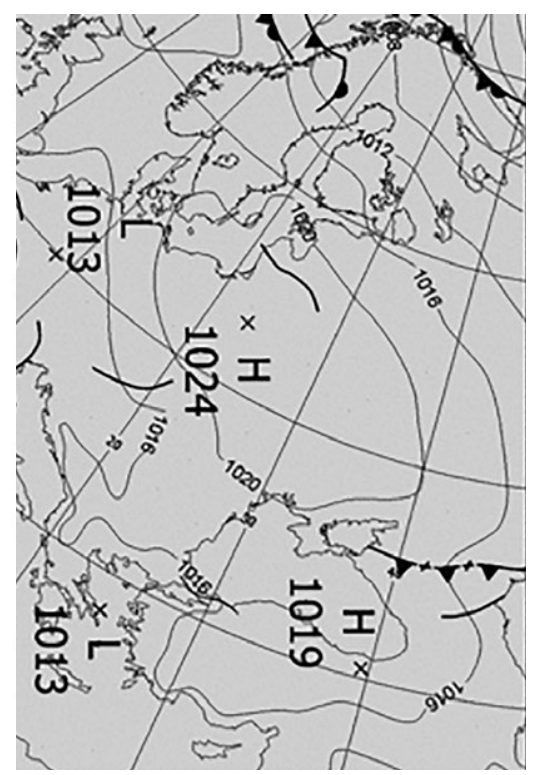

07.06.2018 00h

Fig. 3. Maps of the ground pressure during the fire

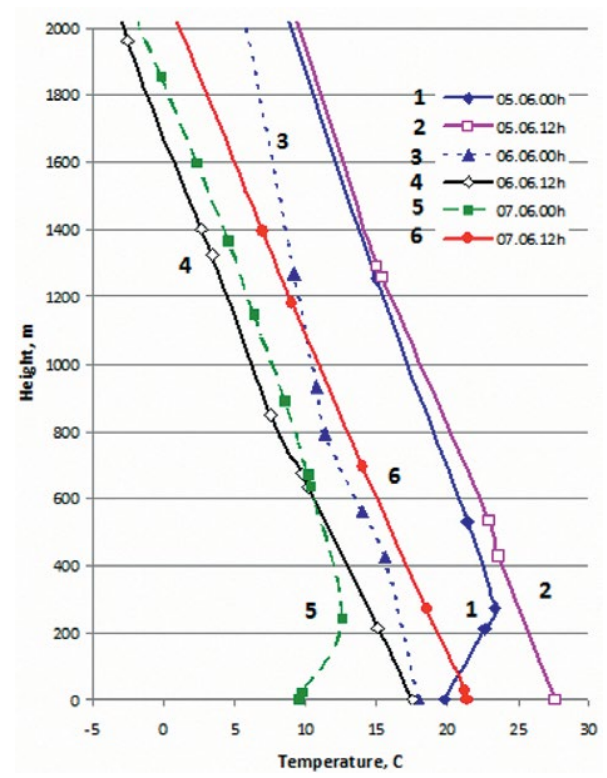

a

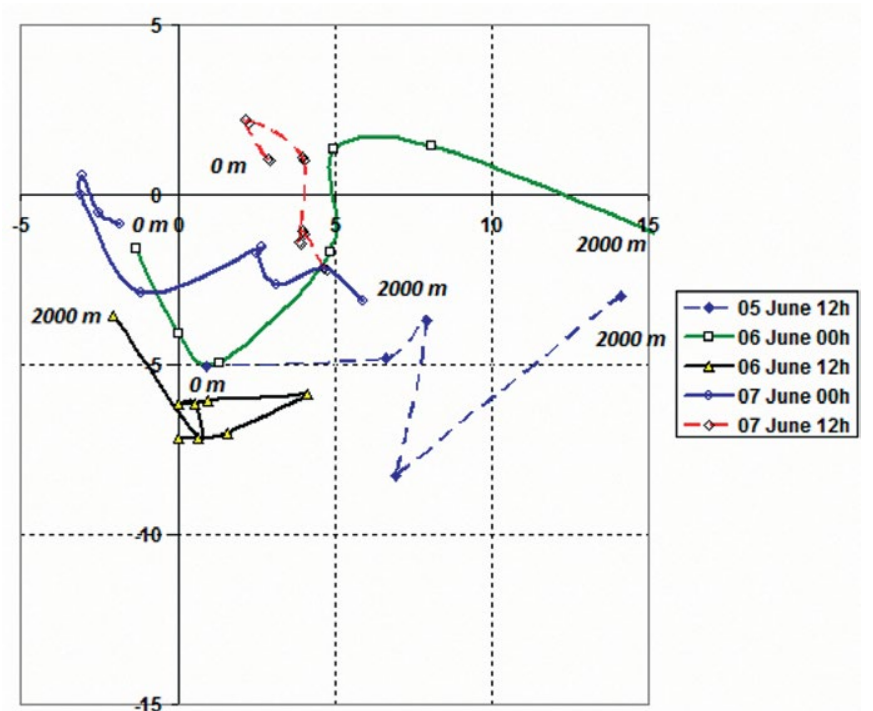

b

Fig. 4. Vertical profiles of the air temperature (a) and the wind velocity (in $\mathrm{m} / \mathrm{s}$ ) hodographs (b) in the layer up to $2 \mathrm{~km}$ according to radiosounding data in Kyiv 


\section{Meteorological conditions during the fire}

The territory of the Exclusion zone on June 5, 2018, was in the low pressure area, in the trough of the north-western cyclone (Fig. 3). At night, a surface temperature inversion and an increase in the wind speed (from 1 to $9 \mathrm{~m} / \mathrm{s}$ ) in the air layer up to $280 \mathrm{~m}$ were observed (Fig. 4). Over the course of the day, a cold front passed over this area resulted in a temperature drop of $27.6{ }^{\circ} \mathrm{C}$ to $17.8^{\circ} \mathrm{C}$ in the afternoon. During the next 3 days there was an increase in atmospheric pressure, which led to the formation of an anticyclone with a centre over the territory of Ukraine and Belarus with the prevailing northern and northwest atmospheric circulation. On June 6-7, 2018, the typical for the summer period vertical profiles of wind have been replaced by a weak wind $(2-3 \mathrm{~m} / \mathrm{s})$ at altitudes up to $1,500 \mathrm{~m}$ and near-surface temperature inversions. It should be noted, that the weak wind or calm with a near-surface temperature inversion contributes to the increased pollution of atmospheric the near-ground air.

\section{Survey of burnt forest areas}

Measurement of the exposure dose rate and sampling of forest litter and top layer of soil was performed on August 22, 2018, to estimate the value of radioactive contamination in 2 burned forest areas (Fig 5). In Fig. 6 54 points of exposure dose measuring in site no. 1 (located 300-400 $\mathrm{m}$ from the ISF-2) are shown and 10 points in site no. 2. The sites are separated by the Chornobyl Pripyat road. Measurement of gamma dose rate values was performed in accordance with the approved method using the dosimeter-radiometer DRG-01T. At each point, measurements were made at heights of $0.1 \mathrm{~m}$ and $1.0 \mathrm{~m}$.

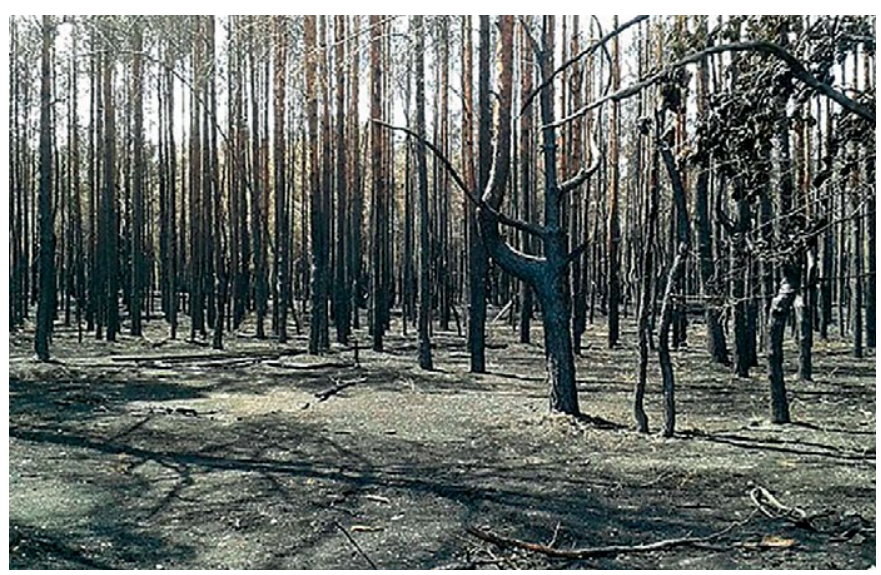

Fig. 5. The area of burned forest

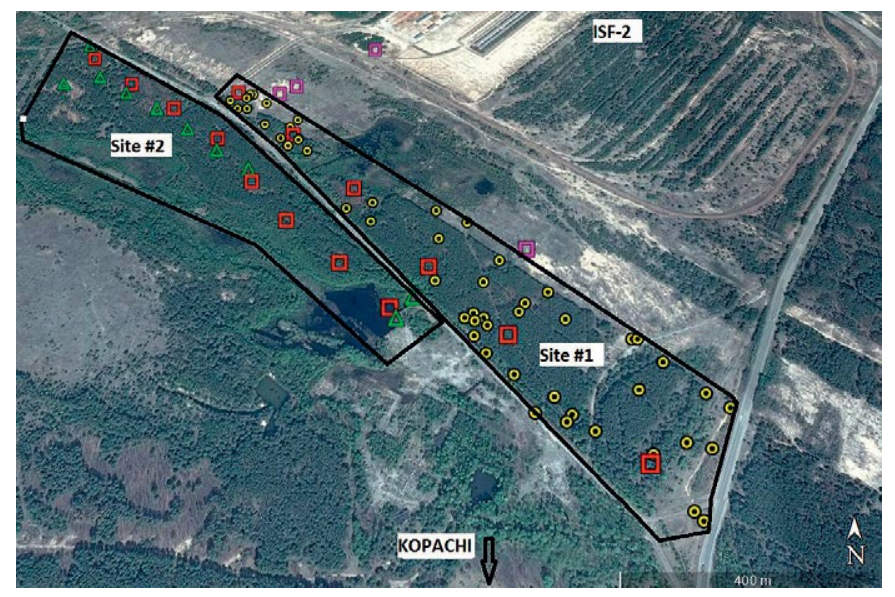

Fig. 6. Measurement places within two sites of burned forest divided by the road (circles and triangles - places of gamma rate measurements in the Site no. 1 and no. 2 accordingly, squares -

places of gamma rate and soil contamination measurements in the Site no. 1, Site no. 2 and outside in the non-burning area)

The distance between measurement points was chosen taking into account the uniformity of contamination and dimensions of the surveyed sites: through every $100 \mathrm{~m}$, starting from the western border of the site and reaching its eastern boundary. After that, the same route was shifted $100 \mathrm{~m}$ to the north until reaching the northern boundaries of the surveyed site.

Measured values of the exposure dose rate in burned areas range from 0.058 to $0.660 \mathrm{mR} / \mathrm{h}$ at a height of $1 \mathrm{~m}$ and from 0.080 to $0.800 \mathrm{mR} / \mathrm{h}$ at a height of $0.1 \mathrm{~m}$ above the ground resulting in the average values of 0.359 and $0.526 \mathrm{mR} / \mathrm{h}$, respectively.

In these areas, in October 2018, sampling of forest litter (ash) and topsoil in 6 points at Site no. 1 and in 10 points in Site no. 2 were carried out. In addition, sampling of soil and litter on a non-burned forest area near the fire territory has been carried out (see Fig. 6). Simultaneously with soil sampling, at each point the gamma dose rate measurement at heights of 0.1 and $1 \mathrm{~m}$ was made. The geographic coordinates of sampling points were determined with using GPS. Soil sampling was carried out according to a unified method to a depth of $3 \mathrm{~cm}$ using a cylindrical sampler with a diameter of $80 \mathrm{~mm}$.

The measurements of the selected samples were carried out using the $\gamma$-spectrometric complex Canberra, consisting of a GL2020R semiconductor detector made of ultra pure germanium with a beryllium window $500 \mu \mathrm{m}$ thick and a multichannel analyzer $(16 \mathrm{~K})$. The minimum measurable activity for the geometry of measurements for the $\gamma$-line $59 \mathrm{keV}$ of ${ }^{241} \mathrm{Am}$ is $0.03 \mathrm{~Bq} / \mathrm{sample}$, and for ${ }^{137} \mathrm{Cs}$ $(661.6 \mathrm{keV})$ is $0.4 \mathrm{~Bq} / \mathrm{sample}$. 
According to measurements of 14 samples, the average value of the density of cesium-137 surface contamination at burned sites was about $2.85 \mathrm{MBq} / \mathrm{m}^{2}$ (with variability of values from 1.02 to $5.40 \mathrm{MBq} / \mathrm{m}^{2}$ ). The value of the exposure dose rate at burned areas varies from 0.245 to $0.845 \mathrm{mR} / \mathrm{h}$ at a height of $1 \mathrm{~m}$ above the ground and from 0.288 to $1.38 \mathrm{mR} / \mathrm{h}$ at a height of $0.1 \mathrm{~m}$.

In Fig. 7 the dependence of the gamma dose rate $H(\mathrm{mR} / \mathrm{h})$ on the density of soil top layer $D\left(\mathrm{MBq} / \mathrm{m}^{2}\right)$ at 14 measurement points in two sites of burned forest is presented. The correlation between them for the measurement height of $h=0.1 \mathrm{~m}$ is sufficiently well described by the linear dependence of $H=0.248 \cdot D$ with the accuracy of approximation $R^{2}=0.707$. For the measurement height of $h=1 \mathrm{~m}$ this dependence is less distinct $\left(R^{2}=\right.$ 0.270 ) and is given by $H=0.149 \cdot D$.

For 6 samples (Tab. 2, four of which were selected at Site no. 2 and two at an adjacent non-burned area), spectrometric measurements of the gamma-emitting ${ }^{154} \mathrm{Eu}$ and ${ }^{241} \mathrm{Am}$ nuclides content were additionally conducted.

The ratio of ${ }^{137} \mathrm{Cs} /{ }^{154} \mathrm{Eu}$ activity in these samples varies almost in 2 times - from 240 to 450 . The ratio of ${ }^{137} \mathrm{Cs} /{ }^{241} \mathrm{Am}$ varies from 22 to 40 , and the ${ }^{241} \mathrm{Am} /{ }^{154} \mathrm{Eu}$ ratio - from 8.9 to 12.4 .

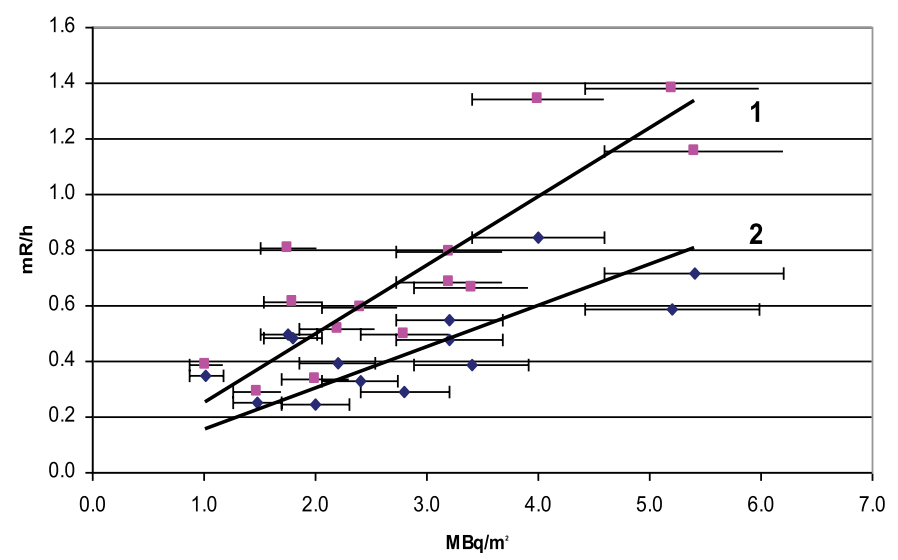

Fig. 7. Dependence of the gamma dose rate $H(\mathrm{mR} / \mathrm{h})$ on the density of soil top layer $D\left(\mathrm{MBq} / \mathrm{m}^{2}\right)$ at two sites of burned forest. Squares and a trend line $1-$ measurement height $0.1 \mathrm{~m}$, diamonds and a trend line $2-$ measurement height $1 \mathrm{~m}$

\section{Modeling resuspension and following atmospheric transport of radioactive aerosols due to the forest fire}

To assess the effects of the fire on June 5-7, 2018, a set of models of the ISP NPP was used, which includes: 1) the mesoscale numerical weather forecast model WRF-ARW; 2) the model for the formation of a convective
Table 2. Data on radionuclide contamination measurement of top soil samples

\begin{tabular}{|c|c|c|}
\hline \multirow{3}{*}{ Pample code } & Nuclide & $\begin{array}{c}\text { Top soil contamination } \\
\text { density, } \mathrm{kBq} / \mathrm{m}^{2}\end{array}$ \\
\hline \multirow{3}{*}{ P2-4 (Site no. 2) } & ${ }^{137} \mathrm{Cs}$ & 457 \\
\cline { 2 - 3 } & ${ }^{154} \mathrm{Eu}$ & 1.30 \\
\cline { 2 - 3 } & ${ }^{241} \mathrm{Am}$ & 15.2 \\
\hline \multirow{3}{*}{ P2-5 (Site no. 2) } & ${ }^{137} \mathrm{Cs}$ & 341 \\
\cline { 2 - 3 } & ${ }^{154} \mathrm{Eu}$ & 0.802 \\
\cline { 2 - 3 } & ${ }^{241} \mathrm{Am}$ & 9.97 \\
\hline \multirow{3}{*}{ P2-8 (Site no. 2) } & ${ }^{137} \mathrm{Cs}$ & 346 \\
\cline { 2 - 3 } & ${ }^{154} \mathrm{Eu}$ & 1.44 \\
\cline { 2 - 3 } & ${ }^{241} \mathrm{Am}$ & 15.4 \\
\hline \multirow{3}{*}{$\begin{array}{c}{ }^{137} \mathrm{Cs} \\
\text { L-2 (non-burning } \\
\text { area) }\end{array}$} & ${ }^{154} \mathrm{Eu}$ & 176 \\
\cline { 2 - 3 } & ${ }^{241} \mathrm{Am}$ & 0.564 \\
\cline { 2 - 3 } & ${ }^{137} \mathrm{Cs}$ & 4.99 \\
\cline { 2 - 3 } & ${ }^{241} \mathrm{Am}$ & 149 \\
\hline \multirow{2}{*}{$\begin{array}{c}\text { L-4 (non-burning } \\
\text { area) }\end{array}$} & ${ }^{137} \mathrm{Cs}$ & 0.454 \\
\cline { 2 - 3 } & ${ }^{154} \mathrm{Eu}$ & 4.59 \\
\cline { 2 - 3 } & ${ }^{241} \mathrm{Am}$ & 127 \\
\hline
\end{tabular}

plume over the fire area - for estimation of the maximum lifting height of radionuclides in the atmosphere at the initial stage of their transport; 3) the Lagrangian-Eulerian diffusion model LEDI of the radionuclide atmospheric transport and their deposition on the surface - for calculating the atmospheric transport of radioactive aerosol particles products at distances up to $100 \mathrm{~km}$.

The results of the WRF-ARW numerical weather forecast model (current version of model V3.9.1) [23] were used as input meteorological information for modeling of radionuclides dispersion released into the atmosphere due to the fire. A numerical grid covering the territory of Ukraine with the center in the vicinity of the Chornobyl NPP was chosen with the number of nodes on the horizontal plane of $144 \times 120$ and the grid step of $5 \mathrm{~km}$. The number of levels in height was set as 35 . Calculations using the WRF-ARW model were performed using the results of the project of data re-analysis from the international meteorological network ERA-40 (global atmospheric reanalysis) performed in European Center for Medium-Range Weather Forecasts (ECMWF) [24].

For the subsequent modeling of atmospheric transport of radioactive aerosol, calculated 3-dimensional fields of wind and air temperature were used, as well as the 


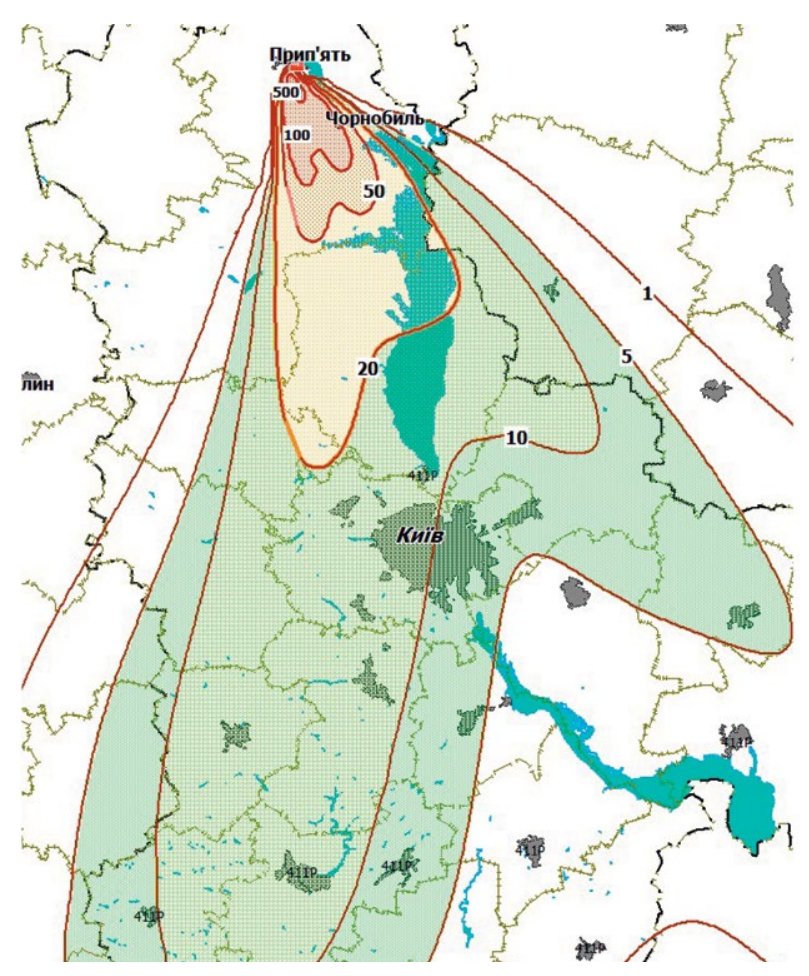

a

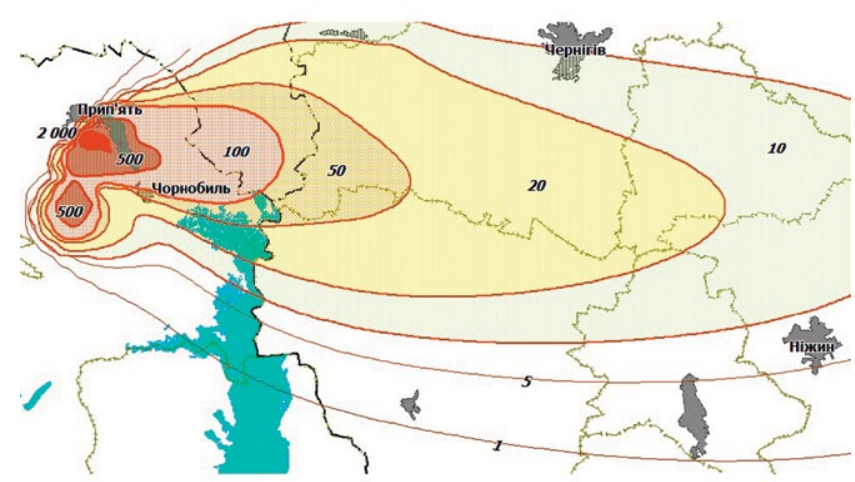

c

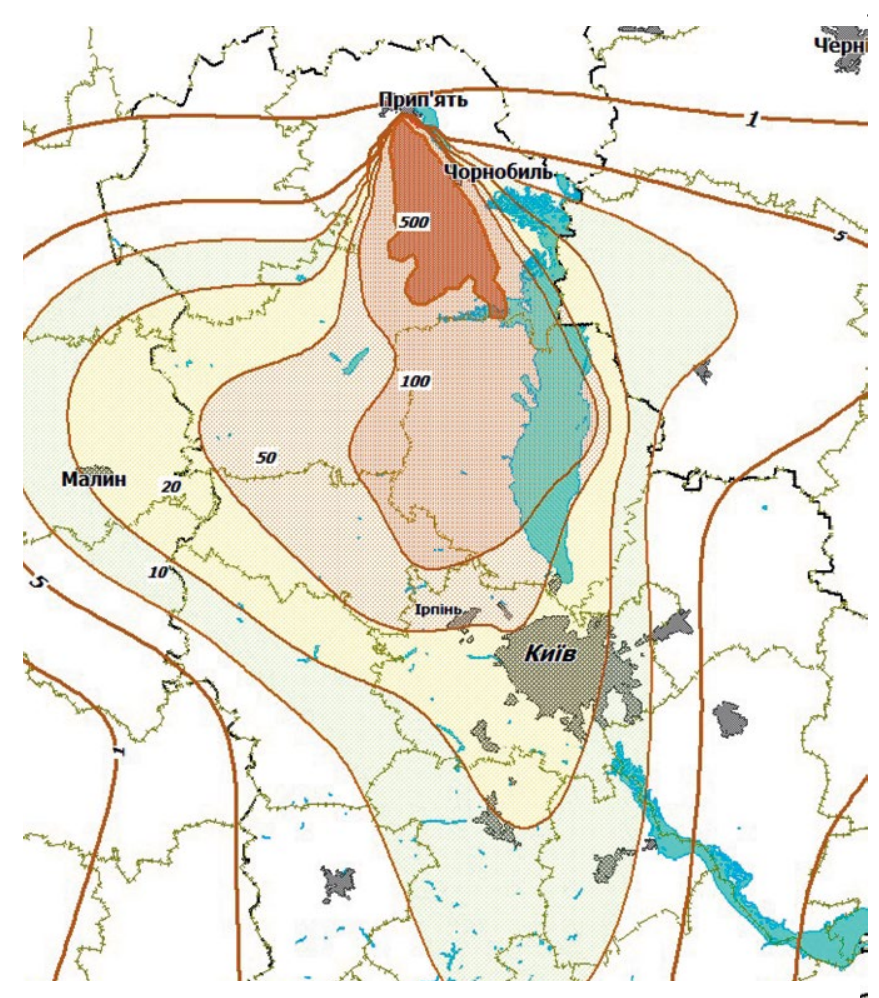

b

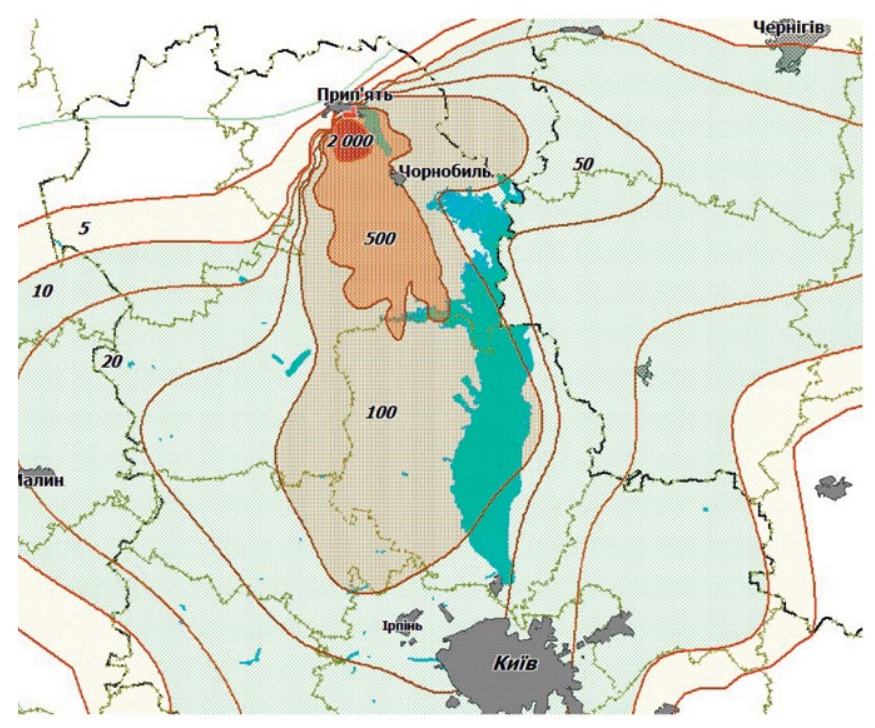

d

Fig. 8. Calculated time-integrated ${ }^{137} \mathrm{Cs}$ activity concentration in the air $\left(\mathrm{Bq} \cdot \mathrm{s} / \mathrm{m}^{3}\right) . a-\mathrm{June} 5, b-\mathrm{J}$ une $6, c-\mathrm{June} 7$, $d$ - a sum for 3 days of the fire (June $5-7,2018$ )

values of characteristics of the atmospheric boundary layer (the atmospheric boundary layer height and the dynamic velocity $u_{*}$ ), obtained with a time step of 1 hour for the period from $00 \mathrm{~h}$ June 5 to $00 \mathrm{~h}$ June 8, 2018.

In the simulations, the fire area is considered as a constant area source of radionuclide emission in the atmosphere. According to the obtained data, the total ${ }^{137} \mathrm{Cs}$ activity in the burning areas was estimated as about $5.510^{11}$ Bq. According to previous studies, the part of activity entering in the air of the forest area was set equal to $5 \%$ of this value. The height of the rise of the smoke plume formed over the fire area was estimated to be about 300-500 m (depending on meteorological conditions during the fire period) with using the above-mentioned model of a convective plume over 


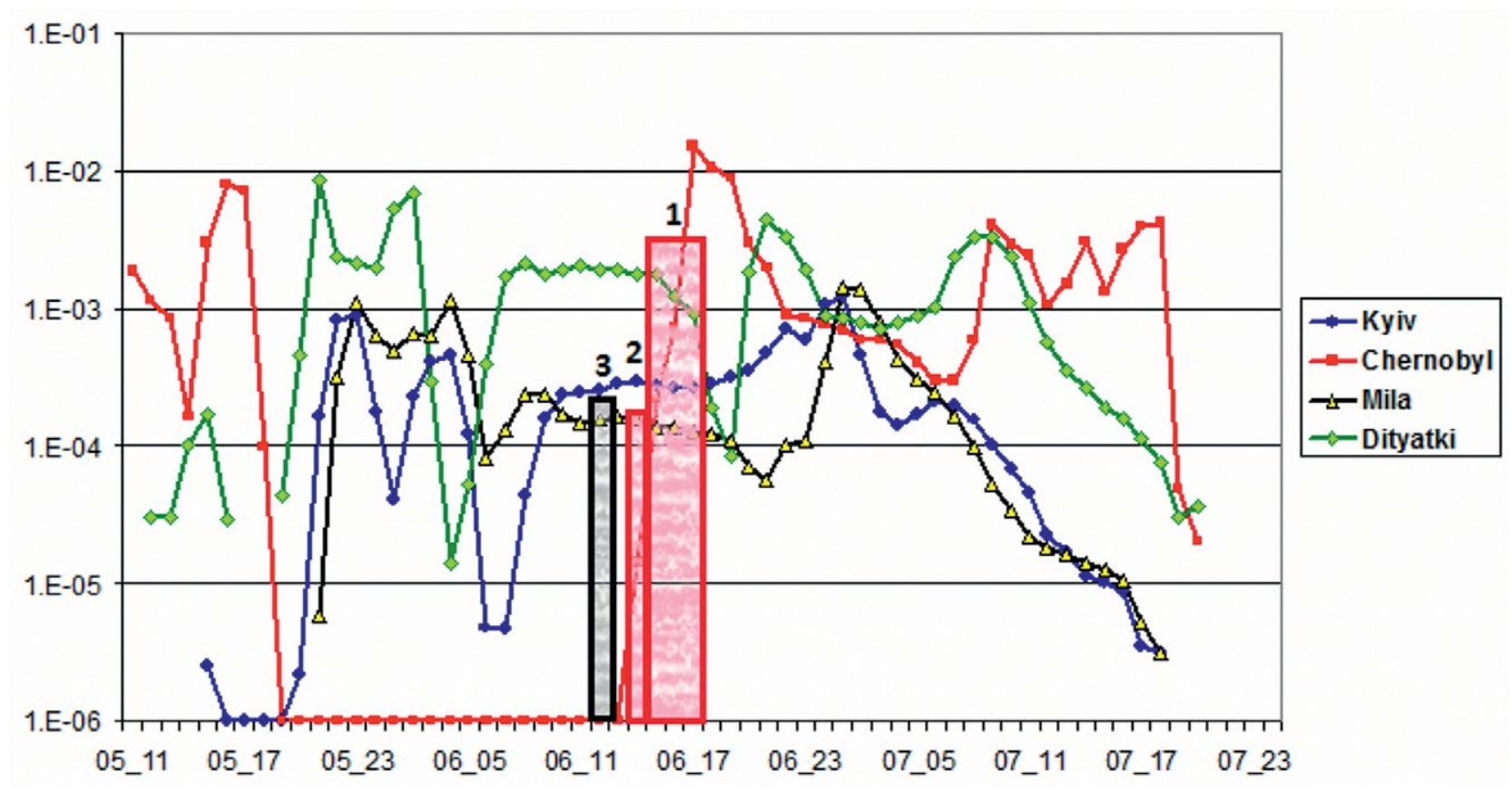

Fig. 9. The modeling dependence of the ${ }^{137} \mathrm{Cs}$ activity in the air $\left(\mathrm{Bq} / \mathrm{m}^{3}\right)$ on time for 4 settlements (lines) compared with the measurement data (columns 1 and 2 - "Ecocenter" data for Chornobyl, column 3 - SSTC NRS data for Mila). Labels on the $\mathrm{X}$ axis are date and hour

the fire area. The radioactive aerosol particle size formed due to the fire was set constant and equal to $1 \mu \mathrm{m}$.

The fields of instantaneous and integral (for the whole period of the fire) of the ${ }^{137} \mathrm{Cs}$ volume activity in the surface air (Fig. 8) and the ${ }^{137}$ Cs deposition density on the earth's surface were calculated using the atmospheric transport model LEDI.

Additionally, ${ }^{137} \mathrm{Cs}$ activity in the air was calculated for 4 settlements: Kyiv, Chornobyl, Dytyatky and Mila (105 km to the south from the Chornobyl NPP). The last settlement was chosen for the calculation because the personnel of the State Scientific and Technical Center for Nuclear and Radiation Safety (SSTC NRS) made a special measurement during the fire with using a mobile laboratory $[25]$. The ${ }^{137} \mathrm{Cs}$ activity in the air in the period from 13:15 to 14:25 on June 6, 2018, was measured to be $0.6 \mathrm{mBq} / \mathrm{m}^{3}$.

According to our calculations, the maximum activity of ${ }^{137} \mathrm{Cs}$ (averaged over a 1-hour period) in the surface air in Kyiv reached $0.82 \mathrm{mBq} / \mathrm{m}^{3}$ at $23 \mathrm{~h}$ on June 5 and $1.22 \mathrm{mBq} / \mathrm{m}^{3}$ at $02 \mathrm{~h}$ on June 7, 2018. For Chornobyl city the estimated maximum ${ }^{137} \mathrm{Cs}$ activity in the air was about $10 \mathrm{mBq} / \mathrm{m}^{3}$ (in the afternoon on June 5 and at $18 \mathrm{~h}$. on June 6,2018 , when the radioactive aerosols transport was directed to the city), and for Dytyatky - it could reach up to $1 \mathrm{mBq} /$ $\mathrm{m}^{3}$. In general, the obtained results are in agreement with the measurements of the cesium-137 activity in the air carried out by the ASKRO networks of the "Ecocenter", as well as the data of SSTC NRS (Fig. 9).

\section{Conclusions}

According to the both direct measurement data and modeling results an increase in the activity concentration in the air during forest fires in the ChEZ is quite low. It does not lead to a significant increase in the dose of the population of Ukraine and other countries. However, the problem of assessing the forest fires danger in the contaminated territories in the ChEZ remains relevant. Each event of a forest fire in the ChEZ attracts the attention of the media and the population living near the ChEZ, including the residents of Kyiv and other major cities. In the case of particularly large and prolonged fires, radioactive aerosols can spread over long distances outside Ukraine, including the countries of Western Europe. Therefore it is necessary to have a reliable means for rapid assessment and prediction of atmospheric transport of radioactive aerosols rising into the air as a result of forest fires. To date, the main problem that requires further research is the development of methods for operational determining the parameters of the forest fire territory as an area non-stationary source of radioactive aerosols. Among them are the following:

1. Rapid assessment and prediction of the territory size covered by a forest fire, including the temporal dynamics of the spread of the fire front. In general, it is necessary to use a special surface fire spread models for the calculation of fire spread over the area taking into account the properties 
of the area and weather conditions. However, these models require detailed information on the characteristics of the forest, which is not always available. These values can be set according to the observations and by expert estimates.

2. Estimations of the value of the radionuclide emission fraction during forest fires are differed considerably - from a few percent to $70 \%$ according to the reviewed experimental and modeling works. The most valid are the results of field experiments and model estimates of the radionuclide emission fraction, carried out for the fires in the ChEZ, which give values $3-5 \%$ of ${ }^{137} \mathrm{Cs}$ and ${ }^{90} \mathrm{Sr}$ and up to $1 \%$ of the $\mathrm{Pu}$ isotopes. Conditions of experiments for biomass burning, for which estimates are obtained from $20 \%$ and above, as a rule, don't fully correspond to the real conditions of the wood burning in a forest fire. In addition, it's necessary to note that in the second year after the deposition the bulk of radionuclides migrates to the forest litter and soil. As a result, the proportion of radionuclides that could potentially be raised to the atmosphere from forest fires, in their total stock in the contaminated area is steadily decreasing over time. Thus, the model estimates of the effects of forest fires on the territory of Ukraine and neighboring countries, obtained using the emission fraction value of $10 \%$ or more, can be considered as very conservative.

3. Effective height of the smoke plume lifting over a forest fire. Its value is determined primarily by the ratio between the kinetic energy of the rising air flow (determined by the intensity of heat release in the fire zone) and the wind kinetic energy.

4. The size distribution of particulate matter formed during burning. The large particles (more than 20 microns) that are formed in a fire, deposited near the burning territory up to 100 meters). Ignoring this factor in the simulation could lead to an overestimation of the long-range transport of radionuclide's, and simultaneously to an underestimation of the value of the additional deposition in the near (up to $100-1000 \mathrm{~m}$ ) fire zone.

Clarification of these parameters values and methods for their reliable estimation will enable to improve models of atmospheric transport of radioactive aerosols rising into the air as a result of forest fires, for a variety of spatial scales.

\section{References}

1. Hao W. M., Bondarenko O. O., Zibtsev S., Hutton D. (2009). Vegetation fires, smoke emissions, and dispersion of radionuclides in the Chernobyl Exclusion Zone. Dev. Environ. Sci., vol. 8, pp. 265-275.

2. Yoschenko V. I., Kashparov V. A., Protsak V. P., Lundin S. M., Levchuk S. E., Kadygrib A. M., Zvarich S. I., Khomutinin Yu.
V., Maloshtan I. M., Lanshin V. P., Kovtun M. V., Tschiersch J. (2006). Resuspension and redistribution of radionuclides during grassland and forest fires in the Chernobyl exclusion zone: Part I. Fire experiments. J. Env. Rad., vol. 86, pp. 143-163.

3. Goldammer J. G., Kashparov V., Zibtsev S., Robinson S. (2015). Best practices to combat wildfires in contaminated areas and recommendations on firemen safety under fires on the radioactive contaminated territories. Global Fire Monitoring Center (GFMC), Freiburg - Basel - Kyiv. (in Russ.)

4. Kashparov V. A., Zhurba M. A., Kireev S. I., Zibtsev S. V., Myronyuk V. V. (2015). Evaluation of expected exposure doses for fire-fighting participants in the Chernobyl exclusion zone in April 2015. Nuclear Physics and Atomic Energy, vol. 16, no. 4, pp. 399-407. (in Russ.)

5. Garger E. K., Kashpur V. A., Skoryak G. G., Gora A. D., Kurochkin A. A., Lisnichenko V. (2004). Aerosol radioactivity and disperse structure at the Chernobyl NPP during the period of forest fires. Agroecol. J., vol. 3, pp. 6-12. (in Russ.)

6. Kulan A. (2006). Seasonal ${ }^{7} \mathrm{Be}$ and ${ }^{137} \mathrm{Cs}$ activities in surface air before and after the Chernobyl event. J. Env. Rad., vol. 90, pp. 140-150. doi: 10.1016/j.jenvrad.2006.06.010.

7. Lujaniene G., Šapolaite J., Remeikis V., Lujanas V., Jermolajev A., Aninkevicius V. (2006). Cesium, americium and plutonium isotopes in ground level air of Vilnius. Czechoslovak Journ. Physics, vol. 56(D), pp. D55-D61. doi: 10.1007/s10582-006-1077-3.

8. Evangeliou N., Balkanski Y., Cozic A., Hao W. M., Mouillot F., Thonicke K., Paugam R., Zibtsev S., Mousseau T. A., Wang R., Poulter B., Petkov A., Yue C., Cadule P., Koffi B., Kaiser J. W., Møller A. P. (2015). Fire evolution in the radioactive forests of Ukraine and Belarus: future risks for the population and the environment. Ecol. Monogr., vol. 85 (1), pp. 49-72.

9. Kashparov V. A., Lundin S. M., Kadygrib A. M., Protsak V. P., Levtchuk S. E., Yoschenko V. I., Kashpur V. A., Talerko N. N. (2000). Forest fires in the territory contaminated as a result of the Chernobyl accident: radioactive aerosol resuspension and exposure of fire-fighters. J. Env. Rad., vol. 51, pp. 281-298.

10. Yoschenko V. I., Kashparov V. A., Levchuk S. E., Glukhovskiy A. S., Khomutinin Yu. V., Protsak V. P., Lundin S. M., Tschiersch J. (2006). Resuspension and redistribution of radionuclides during grassland and forest fires in the Chernobyl exclusion zone: Part II. Modeling the transport processes. J. Env. Rad., vol. 86, pp. 260-278.

11. Evangeliou N., Zibtsev S., Myroniuk V., Zhurba M., Hamburger T., Stohl A., Balkanski Y., Paugam R., Mousseau T. A., Møller A. P., Kireev S. I. (2016). Resuspension and atmospheric transport of radionuclides due to wildfires near the Chernobyl Nuclear Power Plant in 2015: An impact assessment. Scientific Reports, vol. 6: 26062. doi: 10.1038/srep26062.

12. Hohl A., Niccolai A., Oliver C., Melnychuk D., Zibtsev S., Goldammer J. G., Petrenko M., Gulidov V. (2012). The human health 
effects of radioactive smoke from a catastrophic wildfire in the Chernobyl Exclusion Zone: A worst case scenario. J. Earth Bioresources and Life Quality, vol. 1, pp. 1-34.

13. Evangeliou N., Balkanski Y., Cozic A., Hao W. M., Møller A. P. (2014). Wildfires in Chernobyl-contaminated forests and risks to the population and the environment: A new nuclear disaster about to happen. Environ. Int., vol. 73, pp. 346-358.

14. Bogorad V., Lytvynska T., Shevchenko I., Dybach A., Slepchenko O. (2016). Radiation consequences of a fire in the Exclusion zone of the Chernobyl nuclear power plant. Nuclear and Radiation Safety, vol. 69, no. 1, pp. 64-68. (in Russ.)

15. Kovalets I. V., Romanenko A. N., Anulich S. N., Ievdin I. A. (2015). Forecasting of the radioactive contamination by Cs-137 following fires in Chernobyl Exclusion Zone in April-May, 2015. Proceedings of the Decision Support Systems, Theory and Practice Conference (DSS 2015), June 2015, Kiev, Ukraine, pp. 62-65, doi: 10.13140/RG.2.2.20098.79047.

16. Mandel J., Beezley J. D., Kochanski A. K. (2011). Coupled atmosphere-wildland fire modeling with WRF 3.3 and SFIRE2011. Geosci. Model. Dev., vol. 4, pp. 591-610.

17. Ager A. A., Lasko R., Myronuik V., et al. (2019). Managing wildland fire risk and radionuclide resuspension in areas contaminated by the Chernobyl reactor explosion. Sci. Total Environ. (in press).

18. Amiro B. D., Sheppard S. C., Johnston F. L., Evenden W. G., Harris D. R. (1996). Burning radionuclide question: What happens to iodine, cesium and chlorine in biomass fires. Sci. Total Environ., vol. 187, pp. 93-103.

19. Horrill A. D., Kennedy V. H., Paterson I. S., McGowan G. M. (1995). The effect of heather burning on the transfer of radiocaesium to smoke and the solubility of radiocaesium associated with different types of heather ash. J. Env. Rad., vol. 29, pp. 1-10.

20. Wotawa G., De Geer L.-E., Becker A., D’Amours R., Jean M., Servranckx R., Ungar K. (2006). Inter- and intra-continental transport of radioactive cesium released by boreal forest fires. Geophys. Res. Lett., vol. 33, p. L12806. doi: 10.1029/2006GL026206.

21. Hollander W., Garger E. (Eds.) (1996). Contamination of surfaces by resuspended material. Experimental collaboration project No 1, Final report, EUR16527, Office for Official Publications of the European Communities, Luxembourg.

22. Final information on the radiation situation in the Exclusion zone during a fire in 05.06.2018-08.06.2018 (2018). SSE “Ecocenter”, Chornobyl, 7 p. (in Russ.)

23. WRF Portal. Earth System Research Laboratory. Available at: http://esrl.noaa.gov/gsd/wrfportal.

24. European Centre for Medium-Range Weather Forecasts (ECMWF). Available at: http://apps.ecmwf.int/datasets/data/era40-daily/levtype $=$ pl.

25. Bogorad V., Bielov Y., Kyrylenko Y., Lytvynska T., Poludnenko V., Slepchenko O. (2018). Forecast of the consequences of a fire in the
Chernobyl exclusion zone: a combination of the hardware of the mobile laboratory RanidSONNI and computer technologies DSS RODOS. Nuclear and Radiation Safety, vol. 79, no. 3, pp. 10-15. (in Russ.)

\section{М. М. Талерко ${ }^{1}$, Т. Д. Лев ${ }^{1}$, С. I. Кіреєв ${ }^{2}$, В. О. Кашпур ${ }^{1}$, Г. Г. Кузьменко}

${ }^{1}$ Iнститут проблем безпеки АЕС НАН України,

вул. Лисогірська, 12, Київ, 03028, Україна

2 Державне спеціалізоване підприємство "Екоцентр", вул. Шкільна, 6, Чорнобиль, 07270, Україна

\section{Оцінка радіоактивного забруднення повітря внаслідок лісової пожежі в Чорнобильській зоні відчуження 5-8 червня 2018 р.}

Наведено результати моделювання розповсюдження радіоактивних аерозолів, які потрапили в атмосферу в результаті пожежі на ділянках лісу в Чорнобильській зоні відчуження (у районі СВЯП-2) у період 5-8 червня 2018 р. Для оцінки іiі наслідків було використано комплекс моделей Інституту проблем безпеки АЕС НАН України, який включає мезомасштабну модель прогнозу погоди WRF, модель формування конвективного струменя над площею пожежі та лагранжово-ейлерову дифузійну модель LEDI атмосферного перенесення радіонуклідів та іхнього осадження на підстильну поверхню. Модельні розрахунки розповсюдження радіоактивних продуктів горіння виконано на відстані до 100 км від району пожежі. Наведено результати пробовідбору зразків лісової підстилки, що вигоріла, та верхнього шару грунту, виконаних з метою оцінки запасів активності на двох ділянках пожежі. Середнє значення щільності забруднення

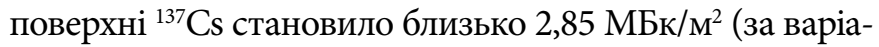
бельності значень від 1,02 до 5,40 МБк/м²). Потужність експозиційної дози на ділянках, що вигоріли, варіювала від 0,288 до 1,38 мР/год. Згідно з розрахунками максимальне значення активності ${ }^{137} \mathrm{Cs}$ у приземному повітрі в Києві в окремі періоди пожежі могло досягати близько

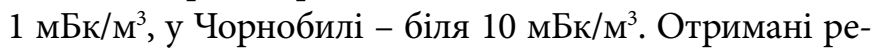
зультати в цілому узгоджуються з даними вимірювань активності ${ }^{137} \mathrm{Cs}$ у повітрі, що проводились мережею постів автоматизованої системи контролю радіаційної обстановки (АСКРО) ДП «Екоцентр», а також даними пробовідбору повітря в с. Міла Київської області (результати Державного науково-технічного центру з ядерної та радіаційної безпеки). Виділено основні проблеми моде- 
лювання вторинного забруднення повітря радіоактивними аерозолями внаслідок лісових пожеж на радіоактивно забрудненій території, що потребують подальшого уточнення при удосконаленні відповідних моделей, а саме: а) інтеграція моделей атмосферного переносу радіонуклідів з моделями розповсюдження фронту пожежі на території, що горить; б) оцінка частки активності, що підіймається в повітря при пожежі, від загального запасу радіонуклідів у лісовій або трав'яній ділянці; в) оцінка ефективної висоти підйому димового струменя над територією пожежі; г) параметризація розподілу аерозольних часток - продуктів горіння за розмірами.

Ключові слова: лісові пожежі, ресуспензія, радіонукліди, атмосферне перенесення, моделювання, Зона відчуження.

\section{Н. Н. Талерко ${ }^{1}$, Т. Д. Лев ${ }^{1}$, С. И. Киреев ${ }^{2}$, В. А. Кашпур ${ }^{1}$, А. Г. Кузьменко ${ }^{1}$}

${ }^{1}$ Институт проблем безопасности АЭС НАН Украины, ул. Лысогорская, 12, Киев, 03028, Украина

${ }^{2}$ Государственное специиализированное предприятие

“Экоиентрр, ул. Школьная, 6, Чернобыль, 07270, Украина

\section{Оценка радиоактивного загрязнения воздуха в результате лесного пожара в Чернобыльской зоне отчуждения 5-8 июня 2018 г.}

Приведены результаты моделирования распространения радиоактивных аэрозолей, попавших в ат- мосферу в результате пожара на участках леса в Чернобыльской зоне отчуждения (в районе ХОЯТ-2) в период 5-8 июня 2018 г. Для оценки его последствий был использован комплекс моделей Института проблем безопасности АЭС НАН Украины, который включает мезомасштабную модель прогноза погоды WRF, модель формирования конвективной струи над площадью пожара и лагранжево-эйлерову диффузионную модель LEDI атмосферного переноса радионуклидов и их осаждения на подстилающей поверхности. Модельные расчеты распространения радиоактивных продуктов горения выполнены на расстоянии до 100 км от района пожара. Приведены результаты пробоотбора образцов выгоревшей лесной подстилки и верхнего слоя почвы, выполненных с целью оценки запасов активности на двух участках пожара. Среднее значение плотности загрязне-

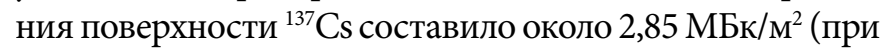
вариабельности этой величины от 1,02 до 5,40 МБк/м²). Согласно расчетам, максимальное значение активности ${ }^{137} \mathrm{Cs}$ в приземном воздухе в Киеве в отдельные периоды пожара могло достигать значений около

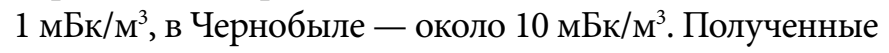
результаты в целом согласуются с данными измерений активности ${ }^{137} \mathrm{Cs}$ в воздухе, проводившихся сетью постов автоматизированной системы контроля радиационной обстановки (АСКРО) ГП “Экоцентр”, а также данными пробоотбора воздуха в с. Мила Киевской области (результаты Государственного научно-технического центра по ядерной и радиационной безопасности).

Ключевые слова: лесные пожары, ресуспензия, радионуклиды, атмосферный перенос, моделирование, Зона отчуждения. 